\title{
Screening of Okra (Abelmoschus esculentus) Cultivars for Resistance against Root Knot Nematode (Meloidogyne incognita) Under Field Condition in Karnataka, India
}

\author{
Kedarnath*, N.G. Ravichandra, D.M. Preethi, B.M.R. Reddy, \\ B.S. Pavithra and R.S. Pavithra
}
Department of Plant Pathology, University of Agricultural Sciences, GKVK, Bengaluru 560065 Karnataka, India
*Corresponding author

A B S T R A C T

\begin{tabular}{|l|}
\hline Ke y w o r d s \\
$\begin{array}{l}\text { Root knot, Field } \\
\text { condition, Synthetic } \\
\text { pesticides. }\end{array}$ \\
\hline Article Info \\
\hline $\begin{array}{l}\text { Accepted: } \\
\text { 26 September } 2017 \\
\text { Available Online: } \\
\text { 10 November } 2017\end{array}$ \\
\hline
\end{tabular}

The southern root-knot nematode (Meloidogyne incognita) is a major soil-inhabiting plant parasite affecting plant growth and causing an estimated $\$ 100$ billion yield loss per year worldwide. Synthetic pesticides, though instantaneously effective, are usually prohibitively expensive, not readily available, may cause hazards to both man and livestock, and inflict injury to the environment. Notable among the alternatives to nematicidesis the use of resistant cultivars, which are inexpensive, and eco-friendly. In the present study, seven okra (Abelmoschus esculentus L.) cultivars were evaluated for their resistance against $M$. incognita under field condition. Among seven cultivars none of the cultivars were found completely resistant. The cultivars ArkaAbhay and Anoop were found to be moderately resistant to M. incognita with root-knot indices of 3.0 (11 to 30 galls) at 60 days after sowing and at harvest. Arkaanamika, Usha, Rashi-20, Akshay and Solar-10 were found susceptible to M. incognita with root-knot indices of 4.0 (31 to 100 galls) at 60 days after sowing and at harvest.

\section{Introduction}

Okra (Abelmoschus esculentus L. Moench) is one of the most popular vegetable crop cultivated throughout India and popular in many tropical and subtropical countries (Singh, 2012). Okra requires a long and warm growing season for optimum growth and development. It is mostly cultivated for human consumption but also for industrial use as fiber (Alegbejo et al., 2008). India is the largest producer of okra in the world with total area of 0.52 million hectares and production of 6.26 million tones green pods, whereas productivity of the crop is $12.1 \mathrm{MT} /$ ha. India is the leading producers of okra but per acre yield of this vegetable in the country is very low due to the attack of fungi, bacteria, viruses and nematodes. Of all the pathogens, root-knot nematodes (Meloidogyne spp.) are among the most serious (Hussain et al., 2011a; Mukhtar et al., 2013a) sedentary endo-parasitic nematode worldwide. Root-knot nematodes are considered among the top five major plant pathogens and the first among the ten most importantgenera of plant parasitic nematodes in the world (Kayani et al., 2013). The 
various species within this genus have an overall host range covering approximately 5500 plant species (Duzyaman, 1997). The species $M$. incognita which is the most important under economic aspects can infect 1,700 plant species (Sigmond, 1976). The annual yield losses caused by Meloidogyne spp. have been estimated up to 16.9 per cent (Bhatti and Jain, 1977; Sasser, 1979; Agrios, 2005). The disease caused by these insidious nematodes is often the only, or one of the few, nematode diseases of crops known to farmers owing to its severe symptoms (Hassan, 2005). These nematodes are worldwide in distribution, attacking a wide range of agricultural crops (Sasser and Freckman, 1987). The overall losses of vegetables caused by root-knot nematodes have been estimated by 50-80 per cent (Sasser, 1979). Root-knot nematodes cause severe growth reductions and formation of galls on okra. Sikora and Fernandez (2005) reported severe attack of root-knot disease caused by Meloidogyne spp. on okra and yield losses up to 27 per cent.

In addition, these parasites also interact with other disease causing organisms to produce disease complexes (Begum et al., 2012) and break down resistance against other pathogens and reduce plant tolerance to environmental stress (Taylor, 1979). The immense losses caused by root-knot nematodes can be minimized by using various control strategies. Soil treatment with chemicals, using biocontrol agents (Mukhtar and Pervaz, 2003; Rahoo et al., 2011; Vagelas and Gowen, 2012) and employing cultural practices such as crop rotation are common methods of nematode control. The use of antagonistic plants as soil amendments has also been found effective (Ahmad et al., 2004; Hussain et al., 2011b; Kayani et al., 2012). However, in a nematode management program, or in any plant protection strategy, these methods should not be the first choice to consider. Although, chemical usage is a common and popular practice to manage nematodes, it can result in an unfavorable cost-benefit ratio and may cause pollution and possible health hazard problems, and conventional nematicides may not be available. Therefore, search for better options has been emphasized. The most effective and economical method is the use of resistant cultivars. Growing resistant cultivars of crops in crop rotations is economical for the farmers for reducing nematode populations gradually in the infested fields. According to Oostenbrink (1966), the cultivation of a resistant variety may suppress a nematode's population to $10-50$ per cent of its harmful density. With reduced multiplication and population density through successive cultivation of resistant varieties for sometimes, it is possible to grow even a susceptible cultivar at frequent intervals without extra cost on the use of nematicides. There is no doubt that if farmers can be provided with resistant varieties of commonly grown crops, they will readily accept them because they do not need to invest extra money. Therefore, availability of resistant varieties is the first information needed for farmers and agricultural scientists. Unfortunately, no sufficient work has been done on okra cultivars for resistance to nematodes in India. Therefore, the objective of the present work was to screen okra cultivars for resistance against root-knot nematode, Meloidogyne incognita (Kofoid and White) Chitwood under sick plot.

\section{Materials and Methods}

\section{Experimental site}

The field experiment was conducted at $M$. incognita infested sick plot maintained at All India Coordinated Research Project (AICRP) on Nematode, Zonal Agricultural Research Station (ZARS), University of Agricultural Sciences, GKVK, Bengaluru, to evaluate the 
level of resistance or susceptibility of the prevailing cultivars of okra. The field is situated at 130' $\mathrm{N}$ latitude and 77' $380 \mathrm{E}$ longitude and an attitude of 899 meters above the mean sea level.

\section{Soil characteristics}

Soil characteristics of the experimental location are red sandy loam in texture. Soil has low to medium water holding capacity in the profile.

\section{Land preparation}

The plot was thoroughly ploughed to a fine tilth, harrowed and leveled. All the normal package of practices like FYM and fertilizers were applied to the plot. The seven okra cultivars were sown in a plot of $2 \times 2 \mathrm{~m}^{2}$ size and the treatments were arranged in completely randomized design with three replications under field condition. All the other normal package of practices like irrigation, fertilizer application and weeding were done uniformly. This experimental plot was divided into micro-plots of $2 \times 2 \mathrm{~m}^{2}$ size and the normal package of practices like irrigation, fertilizer application and weeding were done uniformly to all the plots.

\section{Collection of okra cultivars}

Okra cultivars ArkaAbhay and ArkaAnamika were obtained from Indian Institute of Horticultural Research, Bengaluru and other five commercial cultivars viz., Usha, Rashi20, Akshay, Solar-10 and Anoop were obtained from Department of Horticulture, Bengaluru. These cultivars are widely grown in the varied districts of Karnataka, India.

\section{Data Collected}

The severity of the disease was recorded at sixty days after sowing and at harvest. Five plants were selected in each cultivar of okra and assessed for the susceptible, resistance/tolerance to the nematode. The observations on the number of galls/root system were recorded and the susceptible, tolerant and resistant levels of varieties or cultivars were scored based on the Root-Knot Index on 1 to 5 scale as below (Anon, 1993).

\section{Statistical analysis}

Observations recorded on host parameters and nematodes were subjected to one-way analysis of variance (Sunderaraj et al., 1972). Whenever ' $F$ ' test was found significant, nematodes were compared among themselves.

Critical difference values were calculated for each observation using table ' $t$ ' values at 5 per cent level of significance. Then, the difference between treatment means were compared with the critical difference values to know the significant difference.

\section{Results and Discussion}

Seven commercially available okra cultivars were screened for their reaction to Meloidogyne incognita under field condition and data is presented in Table 1 viz., ArkaAbhay, ArkaAnamika, Usha, Rashi-20, Akshay, Soare plar-10 and Anoop. Data on number of galls and eggmass per plant were recorded at 60 days after sowing and at harvest and depicted in table 1, plate 1 and figure 1. ArkaAnamika recorded maximum number of galls per plant (35.27 and 42.13 galls per plant at 60 days and at harvest respectively with gall indices of 4.0) followed by Usha (33.33 and 40.80 galls per plant with gall indices of 4.0), Solar-10 (32.20 and 36.00 galls per plant with gall indices of 4.0), Rashi20 (31.13 and 33.80 galls per plant with root knot indices of 4.0), Akshay (30.60 and 33.53 galls per plant with root knot indices of 4.0). ArkaAbhay recorded least number of galls per 
plant (11.60 and 22.80 galls per plant at 60 days and at harvest, respectively with root knot indices of 3.0) followed by Anoop (18.63 and 27.07 galls per plant with root knot indices of 3.0).

At 60 days after sowing, there was a significant difference between the cultivars.
However, ArkaAnamika, Usha and Solar-10; Usha, Solar-10, Rasi-20 and Akshay were on par with each other and recorded highest number of galls per root system. At harvest, ArkaAnamika and Usha; solar-10, Rasi-20 and Akshay were on par with each other, which recorded highest number of galls per root system.

Plate.1 Root development in okra cultivars screened against $M$. incognita

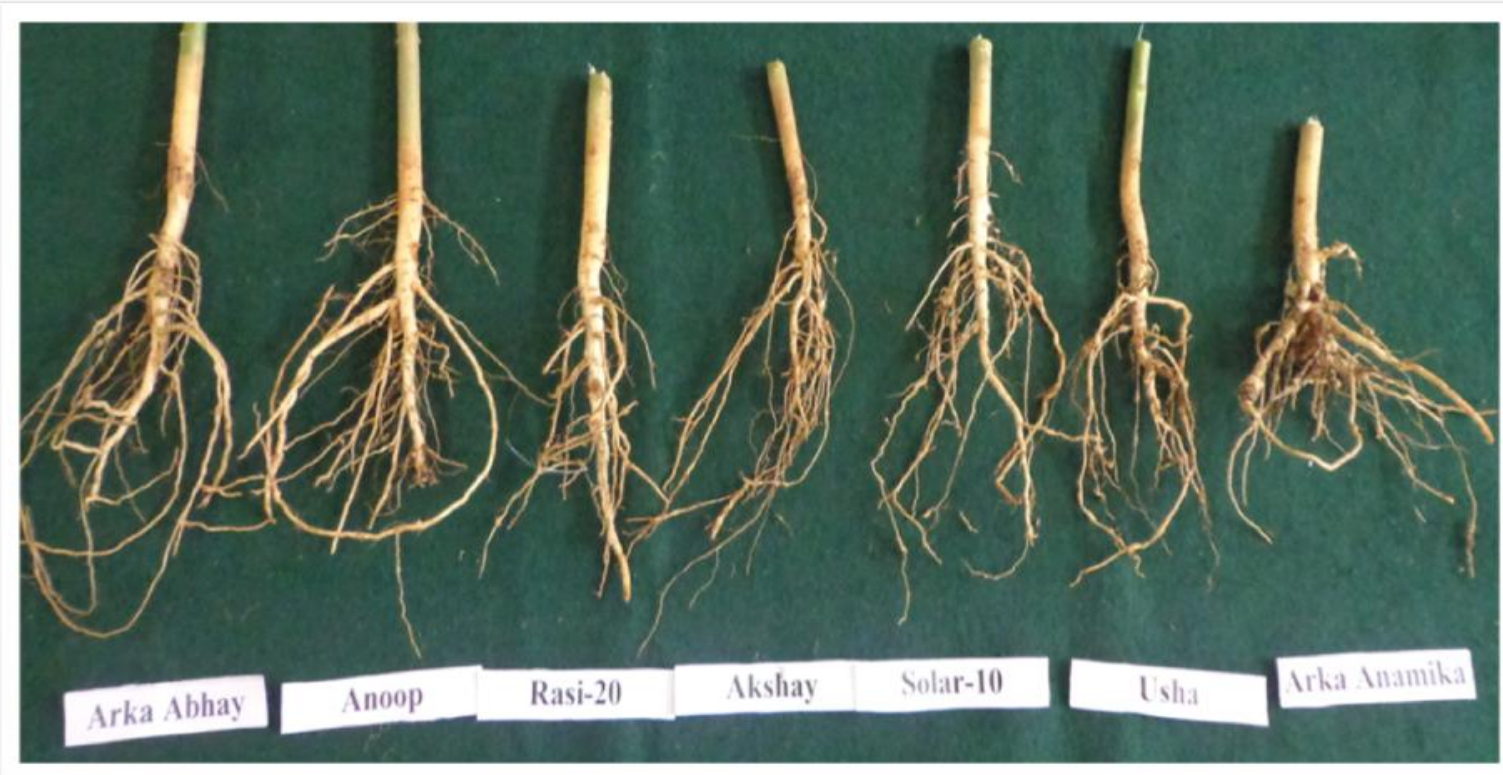

Fig.1 Number of galls produced by different cultivars of okra infested by M. incognita

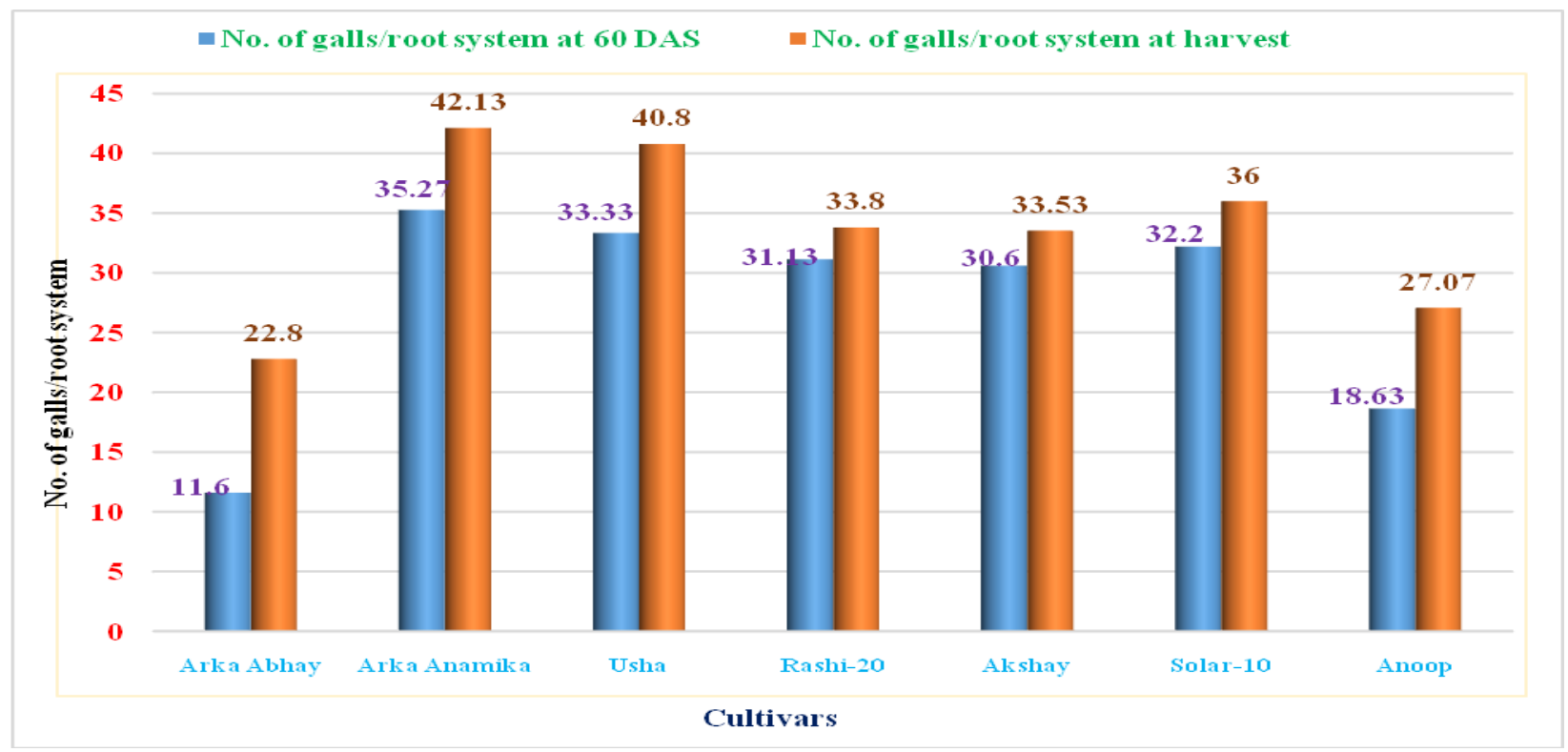


Table.1 Screening of okra cultivars against M. incognita under field condition

\begin{tabular}{|l|c|c|c|c|c|}
\hline \multirow{2}{*}{ Varieties } & \multicolumn{2}{|c|}{ At 60 DAS } & \multicolumn{3}{c|}{ At Harvest } \\
\cline { 2 - 6 } & $\begin{array}{c}\text { Number of } \\
\text { galls/plant }\end{array}$ & $\begin{array}{c}\text { Root-knot } \\
\text { Index }\end{array}$ & $\begin{array}{c}\text { Number of } \\
\text { galls/plant }\end{array}$ & $\begin{array}{c}\text { Root-knot } \\
\text { Index }\end{array}$ & Disease reaction \\
\hline ArkaAbhay & 11.60 & 3.0 & 22.80 & 3.0 & Moderately resistant \\
\hline ArkaAnamika & 35.27 & 4.0 & 42.13 & 4.0 & Susceptible \\
\hline Usha & 33.33 & 4.0 & 40.80 & 4.0 & Susceptible \\
\hline Rashi-20 & 31.13 & 4.0 & 33.80 & 4.0 & Susceptible \\
\hline Akshay & 30.60 & 4.0 & 33.53 & 4.0 & Susceptible \\
\hline Solar-10 & 32.20 & 4.0 & 36.00 & 4.0 & Susceptible \\
\hline Anoop & 18.63 & 3.0 & 27.07 & 3.0 & Moderately resistant \\
\hline S. Em \pm & $\mathbf{1 . 0 1}$ & - & $\mathbf{1 . 2 1}$ & - & - \\
\hline C.D. at 5\% & $\mathbf{3 . 1 1}$ & - & $\mathbf{3 . 7 3}$ & - & - \\
\hline
\end{tabular}

The severity of the disease was recorded at sixty days after sowing and at harvest

$\begin{array}{ll}\text { Number of galls } & \text { Scale } \\ 0 & 1 \\ 1-10 & 2 \\ 11-30 & 3 \\ 31-100 & 4 \\ 101 \text { and above } & 5\end{array}$

The findings of our study showed significant variation among the okra cultivars in response to $M$. incognita. The cultivars ArkaAbhay and Anoop were found moderately resistant to the Meloidogyne incognita (11-30 galls per root systems) at harvest. These cultivars suffered less damage by $M$. incognita as compared to susceptible cultivars viz.,ArkaAnamika and Usha; solar-10, Rasi-20 and Akshay. Cultivation of resistance and moderately resistance cultivars will also help to minimize environmental pollution, preserve the agroecosystems and biodiversity and keep management processes more economical. Furthermore, these cultivars could be used in breeding programs to introduce new resistant cultivars to these nematodes.

Singh et al., (1993) reported that KS-381, KS114 and KSL-380 varieties of okra were resistant and five cultivars were moderately resistant and rests were susceptible to $M$.

\author{
Reaction \\ HR (Highly Resistant) \\ $\mathrm{R}$ (Resistant) \\ MR (Moderately Resistant) \\ S (Susceptible) \\ HS (Highly Susceptible)
}

incognita. Similarly, Rekha and Gowda (2000) reported that okra varieties viz., AROH-10, HOE-202, VLC-1, AROH-9, VB 9101, IIHR-91, and Arkaanamika were susceptible to $M$. incognita. Sheela et al., (2006) reported 123 okra cultivars were moderately resistant with a gall index of 3.0. Mukhtar et al., (2013a) evaluated twelve okra (Abelmoschus esculentus L) cultivars for their resistance against $M$. incognita under field conditions. Ten-day old okra plants of test cultivars were inoculated with 3000 freshly hatched second stage juveniles of $M$. incognita. The nematode caused reductions in various growth parameters of all the cultivars to varying levels over their respective controls. None of the cultivars was found completely resistant. The cultivar 'Sharmeeli' was highly susceptible as >100 galls were recorded on the roots. Sharmeeli also showed maximum reductions in growth among the cultivars evaluated. The cultivars Anmol and 
Sindha were susceptible with 71-100 galls. The cultivars SabzPari, Super Star, PMS55 and PMS Beauty were moderately susceptible with 31-70 galls and comparatively less reductions in growth. Cultivars Sanam, Dikshah, ArkaAnamika, Ikra-1 and Ikra-2 with 11-30 galls were rated as moderately resistant and showed less damage by the nematode as compared to susceptible cultivars and their planting could provide a useful tool to control root-knot nematodes.

\section{References}

Agrios, G. N., 2005. Plant Pathology, fifth ed. Elsevier Academic Press.

Ahmad, M.S., Mukhtar, T., and Ahmad, R., 2004. Some studies on the control of Citrus nematode (Tylenchulus semipenetrans) by leaf extracts of three plants and their effects on plant growth variables. Asian J. Plant Sci. 3, 544548.

Alegbejo, M., Ogunlana, M., and Banwo, O., 2008. Survey for incidence of okra mosaic virus in northern nigeria and evidence for its transmission by beetles. Span. J. Agric. Res. 6, 408-411.

Anonymous, 1993. Consolidated report on rabi pulses plant nematology. All India Coordinated Pulses Improvement Project, Kanpur, 18pp.

Begum, N., Haque, M.I., Mukhtar, T., Naqvi, S.M., and Wang, J.F., 2012. Status of bacterial wilt caused by Ralstonia solanacearum in Pakistan. Pak. J. Phytopathol. 24, 11-20.

Bhatti, D. S., and Jain, R. K., 1977. Estimation of losses in okra, tomato and eggplant yield due to Meloidogyne incognita. Indian J. Nematol. 7, 37-41.

Duzyaman, E., 1997. Okra: Botany and Horticulture. Hortil. Rev.21, 41-72.

Duzyaman, E., and Vural, H.,1997. Evaluation of pod characteristics and nutritive value of okra genetic resources. ActaHorticulturae.598, 103110.

Hassan, N., 2005. Root-knot nematodes on forage crops in India and their management-current status and future thrusts. In: Nehra, S. (Ed.), Plant Diseases, Biocontrol Management. Aavishkar Publishers, Distributors, Jaipur 302003 (Raj) India, pp. 254-284.

Hussain, M.A., Mukhtar, T., and Kayani, M.Z., 2011a. Assessment of the damage caused by Meloidogyne incognita on okra (Abelmoschus esculentus). J. Anim. Plant Sci. 21, 857-861.

Hussain, M.A., Mukhtar, T., and Kayani, M.Z., 2011b. Efficacy evaluation of Azadirachta indica, Calotropis procera, Datura stramonium and Tagetes erecta against root-knot nematodes Meloidogyne incognita. Pak. J. Bot. 43, 197-204 (special issue).

Kayani, M. Z., Mukhtar, T., Hussain, M. A., and Haque, M. I., 2013. Infestation assessment of root-knot nematodes (Meloidogyne spp.) associated with cucumber in the Pothovar region of Pakistan. Crop Prot. 47, 49-54.

Kayani, M.Z., Mukhtar, T., and Hussain, M.A., 2012. Evaluation of nematicidal effects of Cannabis sativa L. and Zanthoxylum alatum Roxb. against rootknot nematodes, Meloidogyne incognita. Crop Prot. 39, 52-56.

Mukhtar, T., Arshad, I., Kayani, M.Z., Hussain, M.A., Kayani, S.B., Rahoo, A.M., Ashfaq, M., 2013a. Estimation of damage to okra (Abelmoschus esculentus) by root-knot disease incited by Meloidogyne incognita. Pak. J. Bot. 45, 1023-1027.

Mukhtar, T., Pervaz, I., 2003. In vitro evaluation of ovicidal and larvicidal effects of culture filtrate of Verticillium chlamydosporium against Meloidogyne javanica. Int. J. Agri. Biol. 5, 576-579.

Oostenbrink, M., 1966. Major Characteristics 
of the relation between nematodes and plants. Mededeelingen van de Landbouwhoge school, Wageningen. 66 (4), 46.

Rahoo, A.M., Mukhtar, T., Gowen, S.R., and Pembroke, B., 2011. Virulence of entomopathogenic

Xenorhabdus bovienii and Photorhabdus luminescens against Galleria mellonella larvae. Pak. J. Zool. 43, 543-548.

Rekha, A. R., and Gowda, D. N., 2000. Screening of okra germplasm and varieties for resistance against Meloidogyne incognita. Indian $J$. Nematol.30, 249.

Sasser, J. N. 1979. Economic importance of Meloidogyne in tropical countries. In: Lamberti, F., Taylor, C.E. (Eds.), Rootknot nematodes (Meloidogyne spp.): Systematics, biology and control. Academic Press, New York. 359-374.

Sasser, J.N., 1979. Economic importance of Meloidogyne in tropical countries. In: Lamberti, F., Taylor, C.E. (Eds.), Rootknot nematodes (Meloidogyne spp): Systematics, Biology and Control. Academic Press, New York, pp. 359374.

Sasser, J.N., and Freckman, D.W., 1987. A world perspective on Nematology. The role of society. In: Veech, J.A., Dickson, D.W. (Eds.), Vistas on Nematology. SON. Inc, Hyattsville, MD, USA, pp. 7-14.
Sheela, M. S., Jiji, R., Malu and Shaiju, S., 2006. Screening of okra varieties for resistance against Meloidogyne incognita. Indian J. Nematol.36,292293.

Sigmond, N. W., 1976.Evolution of crop plants. Longman Publishers Limited, London, 237.

Sikora, R. A., and Fernandez, E. 2005. Nematode parasites of vegetables. In: Luc, M., Sikora, R. A., Bridge, J. (Eds.), Plant parasitic nematodes in subtropical and tropical agriculture. CABI Publishing, London, UK, pp. 319-392.

Singh, D., 2012. Genetic control of aluminium tolerance in okra (Abelmoschus esculentus (L.) Moench). Sci. HorticE Amsterdam. 138, 134-137.

Singh, R. K., Singh, R. R., and Pandey, R. C., 1993. Screening of okra, Abelmoschus esculentus varieties/cultivars against root-knot nematode, Meloidogyne incognita. Curr. Nematol. 4, 229-232.

Taylor, C.E., 1979. Meloidogyne interrelationships with microorganisms. In: Lamberti, F., Taylor, C.E. (Eds.), Root-knot nematodes (Meloidogyne Species). Academic Press, London, New York, pp. 375398.

Vagelas, I., and Gowen, S.R., 2012. Control of Fusarium oxysporum and root-knot nematodes (Meloidogyne spp.) with Pseudomonas oryzihabitans. Pak. J. Phytopathol. 24, 32-38.

\section{How to cite this article:}

Kedarnath, N.G. Ravichandra, D.M. Preethi, B.M.R. Reddy, B.S. Pavithra and Pavithra, R.S. 2017. Screening of Okra (Abelmoschus esculentus) Cultivars for Resistance against Root Knot Nematode (Meloidogyne incognita) Under Field Condition in Karnataka. Int.J.Curr.Microbiol.App.Sci. 6(11): 3420-3426. doi: https://doi.org/10.20546/ijcmas.2017.611.402 